\title{
THE JUGULAR FORAMEN: COMPARTMENTALISATION
}

\author{
Sandeep Arora ${ }^{1}$
}

${ }^{1}$ Assistant Professor, Department of Anatomy, Sri Venkateshwara Medical College Hospital and Research Centre, Ariyur, Puducherry.

\section{ABSTRACT}

The study was designed to measure the diameters of jugular foramen and correlates the measurements with clinical importance. The bony bridging of the jugular foramen is established by the contact of the intrajugular process of the temporal bone with the bony process of the occipital bone projecting either from just above the hypoglossal canal or from posterior to the hypoglossal canal. If both the processes of the occipital bone reach the intrajugular process of the temporal bone simultaneously, it is divided into three compartments. As observed during the study, a lot of variation in measurements of jugular foramen was seen. Even among Indians there was difference noted, so the operating surgeon should keep in mind the differences in measurements.

\section{KEYWORDS}

Jugular Foramen, Diameters, Skull Base.

HOW TO CITE THIS ARTICLE: Arora S. The jugular foramen: compartmentalisation. J. Evolution Med. Dent. Sci. 2016; 5(53):34833485, DOI: $10.14260 /$ jemds/2016/804

\section{INTRODUCTION}

The skull base is a platform at the bottom of the cranium that cradles the brain, provides support, protection and serves as the entrance and exit for major vascular and neural structures.[1]

One of the important foramen in the norma basalis is jugular foramen, which is the main route of venous outflow from the skull and is characterized by laterality based on the predominance of one of the sides. Ligat of the IJV is sometimes performed during radical neck dissection with the risk of various interaction, which some adduce to be due to ligation of the dominant IJV.[2]

Advancements in microsurgical techniques have made possible the removal of advanced jugular foramen lesions, which were one assumed to be inoperable. As neurosurgeons become bolder in approaching this region, so the need for familiarity with the detailed anatomy of this region becomes greater. The difficulties in exposing this foramen are created by its deep location and the surrounding vital structures, such as the carotid artery anteriorly, the hypoglossal nerve medially, the facial nerve laterally and the vertebral artery inferiorly. All these important structures require careful dissection during access to this foramen.[3]

Modern surgical procedure, anaesthesia as well as acupuncture practice require more precise understanding of the surrounding anatomy of various foramina.[4] Many important nerves and vessels pass in and out of the skull via openings termed foramina.[5] Recent advances in CT have produced a growing need for precise information about optimal scanning positions for examining the morphological and metrical details of the foramina and canals in the base of the skull. Knowledge of the normal and variant positions of the canals and foramina of the skull base is important for radiologists, neurosurgeons and anatomists, because of the increasingly refined techniques available.[6]

Financial or Other, Competing Interest: None.

Submission 18-02-2016, Peer Review 03-06-2016,

Acceptance 09-06-2016, Published 01-07-2016.

Corresponding Author:

Dr. Sandeep Arora,

Ward No. 1, Street No. 8,

Backside Raman Cinema,

Mansa-151505

E-mail: drsamarora03@rediffmail.com

DOI: 10.14260/jemds/2016/804

\section{MATERIALS AND METHODS}

Thirty human skulls available in the Department of Anatomy, Dayanand Medical College and Hospital, Ludhiana, were studied after approval of Hospital Ethics Committee. All the skulls selected were dry, complete and showed normal anatomical features. Skulls showing pathological changes, evidence of any previous trauma or skeletal disorders were excluded from this study.

\section{RESULTS}

\begin{tabular}{|c|c|c|c|c|c|}
\hline Parameter & Side & Mean & SD & Range & SEM \\
\hline \multirow{2}{*}{ MAPD } & R & 18.61 & 2.43 & $13.14-24.12$ & 0.44 \\
\cline { 2 - 6 } & $\mathrm{L}$ & 17.76 & 2.2 & $13.22-23.90$ & 0.40 \\
\hline \multirow{2}{*}{ MTD } & $\mathrm{R}$ & 11.38 & 1.85 & $8.18-15.10$ & 0.34 \\
\cline { 2 - 6 } & $\mathrm{L}$ & 9.99 & 1.76 & $6.36-14.52$ & 0.32 \\
\hline
\end{tabular}

Table 1: Measurements of Jugular Foramen (In mm)

\begin{tabular}{|c|c|c|c|c|}
\hline \multirow[b]{2}{*}{$\begin{array}{l}\text { Range of MAPD of } \\
\text { Jugular Foramen }\end{array}$} & \multicolumn{2}{|c|}{ Right } & \multicolumn{2}{|c|}{ Left } \\
\hline & 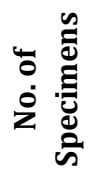 & 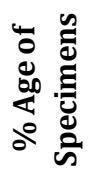 & 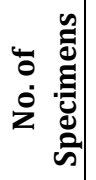 & 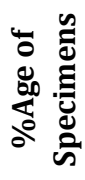 \\
\hline $12.01-14.00$ & 1 & 3.33 & 1 & 3.33 \\
\hline $14.01-16.00$ & 3 & 10 & 4 & 13.33 \\
\hline $16.01-18.00$ & 6 & 20 & 10 & 33.33 \\
\hline $18.01-20.00$ & 11 & 36.67 & 12 & 40 \\
\hline $20.01-22.00$ & 7 & 23.33 & 2 & 6.67 \\
\hline $22.01-24.00$ & - & - & 1 & 3.33 \\
\hline $24.01-26.00$ & 2 & 6.67 & - & - \\
\hline Total & 30 & 100 & 30 & 100 \\
\hline $\begin{array}{r}\text { Table 2: D } \\
\text { of Jug }\end{array}$ & $\begin{array}{l}\text { futio } \\
\text { For }\end{array}$ & $\begin{array}{l}\text { ange } \\
\text { (Inn }\end{array}$ & MAPD & \\
\hline
\end{tabular}

Maximum number of cases in each part is highlighted. 


\begin{tabular}{|c|c|c|c|c|}
\hline \multirow[b]{2}{*}{$\begin{array}{l}\text { Range of } \\
\text { MTD of } \\
\text { Jugular } \\
\text { Foramen }\end{array}$} & \multicolumn{2}{|c|}{ Right } & \multicolumn{2}{|c|}{ Left } \\
\hline & 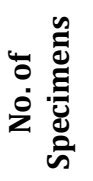 &  & 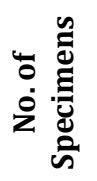 &  \\
\hline $6.01-8.00$ & - & - & 2 & 6.67 \\
\hline $8.01-10.00$ & 6 & 20 & 14 & 46.67 \\
\hline $10.01-12.00$ & 10 & 33.33 & 10 & 33.33 \\
\hline $12.01-14.00$ & 11 & 36.67 & 3 & 10 \\
\hline $14.01-16.00$ & 3 & 10 & 1 & 3.33 \\
\hline Total & 30 & 100 & 30 & 100 \\
\hline . & -1 & סJ 1 & MTL & lar \\
\hline
\end{tabular}

Maximum number of cases in each part is highlighted.

\begin{tabular}{|c|c|c|c|c|c|}
\hline \multirow{4}{*}{$\begin{array}{c}\text { JF } \\
\text { DOME }\end{array}$} & & \multicolumn{2}{|c|}{ Right } & \multicolumn{2}{|c|}{ Left } \\
\hline & & 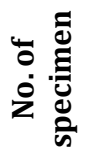 & 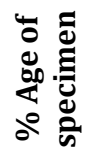 & 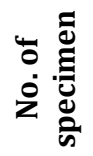 & 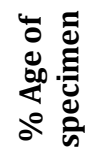 \\
\hline & Absent & 10 & 33.33 & 16 & 53.33 \\
\hline & Present & 20 & 66.67 & 14 & 46.67 \\
\hline
\end{tabular}

Maximum number of cases in each part is highlighted.

\begin{tabular}{|c|c|c|c|c|c|}
\hline Parameter & & \multicolumn{2}{|c|}{ Right } & \multicolumn{2}{c|}{ Left } \\
\hline \multirow{3}{*}{ Septation } & & $\begin{array}{c}\text { No. of } \\
\text { Specimen }\end{array}$ & $\begin{array}{c}\text { \% Age of } \\
\text { Specimen }\end{array}$ & $\begin{array}{c}\text { No. of } \\
\text { Specimen of }\end{array}$ & \begin{tabular}{c} 
Specimen \\
\cline { 2 - 6 }
\end{tabular} \\
\cline { 2 - 6 } & Absent & 17 & 56.67 & 16 & 53.33 \\
\cline { 2 - 6 } & Partial septation & 13 & 43.33 & 13 & 43.33 \\
\hline & Complete septation & 0 & 0 & 1 & 3.33 \\
\hline \multicolumn{3}{|c}{ Table 5: Presence or Absence of Jugular Foramen Septation } \\
\hline
\end{tabular}

Maximum number of cases in each part is highlighted.

\begin{tabular}{|c|c|c|c|c|c|}
\hline \multicolumn{2}{|c|}{ R=L } & \multicolumn{2}{c|}{ R>L } & \multicolumn{2}{c|}{ \% $>\mathbf{R}$} \\
\hline No. of Specimen & \% of Specimen & No. of Specimen & \% of Specimen & No. of Specimen & \% of Specimen \\
\hline 4 & -13.33 & 18 & 60 & 8 & 26.67 \\
\hline \multicolumn{2}{|r|}{ Table 6: Showing Symmetry of Jugular Foramen } \\
\hline
\end{tabular}

Maximum number of cases in each part is highlighted.

\begin{tabular}{|c|c|c|c|c|c|}
\hline \multirow{3}{*}{ Para-meter } & \multirow{2}{*}{ Shape } & \multicolumn{2}{|c|}{ Right } & \multicolumn{2}{c|}{ Left } \\
\cline { 2 - 6 } & No. of Specimen & $\begin{array}{c}\text { \% Age of } \\
\text { Specimen }\end{array}$ & $\begin{array}{c}\text { No. of Specimen of of } \\
\text { Specimen }\end{array}$ \\
\hline \multirow{3}{*}{ JF } & Circular & 1 & 3.33 & - & - \\
\cline { 2 - 6 } & Ovale & 4 & 13.33 & 3 & 10 \\
\cline { 2 - 6 } & Elongated ovale & 2 & 76.67 & 24 & 80 \\
\cline { 2 - 6 } & Irregular & 23 & 76.67 & \\
\hline
\end{tabular}

Maximum number of cases in each part is highlighted.

\section{DISCUSSION}

1. MAPD of JF in our study is $18.61 \pm 2.43 \mathrm{~mm}$ (Range 13.14 $24.12 \mathrm{~mm}$ ) on right side and $17.76 \pm 2.20 \pm 2.20 \mathrm{~mm}$ (Range $13.22-23.90 \mathrm{~mm}$ ) on left side. Higher results as compared to others. $[7,8]$

2. MTD of Jugular Foramen in our study is $11.38 \pm 1.85 \mathrm{~mm}$ (Range 8.18-15.10 mm) on right side and $9.99 \pm 1.76 \mathrm{~mm}$ (Range 6.36-14.52 mm) on left side. MTD lower as compared to previous studies.[9,10]

3. Septa within some rare difference exists.[11,12,13]

4. Jugular foramen dome variation is due to the dissimilarity in the racial and the geographical source of study material.

Dominance 01 - RT sided 14.60.[14,15]

\section{SUMMARY}

Abnormal enlargement of jugular foramen is seen in glomus jugulare tumour, metastatic tumour, reticulo endo helicis and neuronas of IX, X, XI cranial nerves. A lot of variation in measurements of JF were seen. Even among Indians there was difference noted, so the operating surgeon should keep in mind the differences in measurements.

\section{REFERENCES}

1. Nemzek WR, Brodie HA, Hecht ST, et al. MR, CT, and plain film imaging of the developing skull base in fetal specimens. AJNR 2000;21(9):1699-706.

2. Karasu A, Cansever T, Batay F, et al. The microsurgical anatomy of the hypoglossal canal. Surg Radiol Anat 2009;31(5):363-7.

3. Idowu OE. The jugular foramen-a morphometric study. Folia Morphol 2004;63(4):419-22.

4. Elias MG, Silva RB, Pimentel ML, et al. Morphometric analysis of the infraorbital foramen and accessories foraminas in Brazilian skulls. Int J Morphol 2004;22(4):273-8. 
5. Standring S. External skull. In: Standring S, Borley NR, Collins P, et al. Gray's Anatomy: The anatomical basis of clinical practice. $40^{\text {th }}$ ed. Elsevier Churchill Livingstone 2008:409-21.

6. Berlis A, Putz R, Schumacher M. Direct and CT measurements of canals and foramina of the skull base. The British Journal of Radiology 1992;65(776):653-61.

7. Berge JK, Bergman RA. Variations in size and in symmetry of foramina of the human skull. Clin Anat 2001;14(6):40613.

8. Anand MK, Singh PR, Raibagkar CJ, et al. Comparison of foramina on both sides of dry human skulls. J Anat Soc India 2002;51(1):131-249.

9. Ekinci N, Unur E. Macroscopic and morphometric investigation of the jugular foramen of the human skull. Kaibogaku Zasshi 1997;72(6):525-9.
10. Wysocki J. Morphology of the temporal canal and postglenoid foramen with reference to the size of the jugular foramen in man and selected species of animals. Folia Morphol 2002;61(4):199-208.

11. Shapiro R. Compartmentalisation of the jugular foramen. J Neurosurg 1972;36(3):340-3.

12. Dodo Y. Observations on the bony bridging of the jugular foramen in man. J Anat 1986;144:153-65.

13. DeSouza FM, Nateker PE. Partitioning of jugular foramen. Indian Journal of Otology 2008;14:33-6.

14. Sturrock RR. Variations in the structure of the jugular foramen of the human skull. J Anat 1988;160:227-30.

15. Hatiboglu MT, Anil A. Structural variations in the jugular foramen of the human skull. J Anat 1992;180(Pt 1):191-6. 